\title{
Study of Haemovigilance in A Tertiary Care Teaching Hospital Inandhrapradesh
}

\author{
Asha Latha Muppur ${ }^{1}$, Padmavathi ${ }^{2}$,Shareef $\mathrm{SM}^{3}{ }^{3}$,Kiran Reddy $\mathrm{KP}^{4}$ \\ 'Associate professor,Department of pharmacology,RIMS,Kadapa,Dr NTR university of health \\ sciences,Andhrapradesh,INDIA) \\ (Assistant professor,Department of pharmacology,RIMS,Kadapa,Dr NTR university of health \\ sciences,Andhrapradesh,INDIA) \\ (Assisstant professor,Department of pharmacology,RIMS,Kadapa,Dr NTR university of health \\ sciences,Andhrapradesh,INDIA) \\ (Assisstant professor,Department of pharmacology,RIMS, Kadapa,Dr NTR university of health \\ sciences,Andhrapradesh,INDIA
}

\begin{abstract}
Introduction:Haemovigilance is a set of surveillance procedures covering the whole transfusion from collection of blood and its components to the follow up of its recepients. Haemovigilance programe of India was launched on $10^{\text {th }}$ December 2012 .
\end{abstract}

Objective:To identify and prevent occurence or recurrence of transfusion related unwanted events and to increase the safety, efficacy and efficiency of blood transfusion.

Materials And Methods:Transfusion reactions reported over a period of 3 months(march,april,may 2016)were reviewed and analysed.

Results:A total of 2445 units of whole blood and components were transfused in this period.In this 1330 units of whole blood,950 units of packed cells, 65 units of platelet rich plasma and 100 units of fresh frozen plasma were transfused.Acute transfusion reactions(ATR) encountered were 16(0.65\%).Out of which ATRs with whole blood were $(n=7, p=0.13)$, with packed cells were $(n=2, p=0.19)$, with platelets were $(n=4, p=0.18)$ and with frozen plasma were $(n=3, p=0.53)$.Allergic reactions were most common ATRs seen with whole blood transfusions.Febrile reactions were the second most ATRs.Least number of ATRs are seen with packed cells.Obstetrics and gynaecology department recieved most of blood transfusions(58.27\%), while paediatric department stood second $(8.6 \%)$.

Conclusion:The overall incidence of ATRs in this hospital is 0.65\%.Though there are no leucoreduction facilities, the ATRs are less due strict aseptic compatability testing.

Keywords: Haemovigilance, Acute transfusion reactions,Febrile reactions, Allergy, Whole blood transfusion.

\section{Introduction}

Blood transfusion is lifesaving in critically ill patients.Blood transfusion typically uses sources of someone eles(allogenic or homologous transfusion)or ones own(autologous transfusion).Before transfusion $\mathrm{ABO}$ compatability and $\mathrm{Rh}$ compatability is tested ${ }^{[1]}$. Donated blood is then separated into components like RBC,plasma,platelets,albumin,clotting factor concentrate, cryoprecipitate,fibrinogen,immunoglobulins and packed cells.In this institute only packed cells,platelets rich plasma,fresh frozen plasma and whole blood are available for transfusion.

Haemovigilance is a tool to improve the quality of blood transfusion chain,primarily focusing on safety $^{[2]}$.Haemovigilance systems have shown that blood transfusion is relatively safe and majority of adverse reactions are preventable.Haemovigilance is used for surveillance of alternatives for allogenic blood transfusions ${ }^{[3]}$.

Initiation of software development for Haemovigilance programme in India (HVPI)was started on $15^{\text {th }}$ November ,2012.Haemovigilance software was uplinked on national institute of biology on 24 th January.There are about 2545 licensed blood banks out of which 981(38.5\%)are in public sector and remaining 1564 are in private hospital or managed by charitable or voluntary organizations ${ }^{[4]}$. The average annual blood collection is around 7-8 million units in our country ${ }^{[6]}$.There are 134 centers for HVPI,out of which 35 are at north zone,23 at west zone,18 at east zone and 58 at south zone.Targets for HVPI are Initiation phase 2012-13,expansion and consolidation phase 2013-15 and expansion and maintanence phase 2015-17.

\section{Materials And Methods}

The study was conducted in the department of pharmacology and blood bank of Rajiv Gandhi Institute of medical sciences(RIMS),kadapa,Andhrapradesh.The Institutional Ethics committee of RIMS ,Kadapa during 
its meeting held on $15^{\text {th }}$ march 2015 heard the presentation and gave approval.A prospective observational study was done for 3 months ie on march,april,may 2016 during which acute transfusion reactions occuring in various departments in RIMS were reviewed and analysed ${ }^{[7]}$.

Before a recipient receives a transfusion, compatibility testing between donor and recipient blood is done. The first step before a transfusion is given is to type and screen the recipient's blood. Typing of recipient's blood determines the $\mathrm{ABO}$ and $\mathrm{Rh}$ status. The sample is then screened for any alloantibodies that may react with donor blood. It takes about 45 minutes to complete .

A positive screen warrants an antibody panel/investigation to determine if it is clinically significant. An antibody panel consists of commercially prepared group $\mathrm{O}$ red cell suspensions from donors that have been phenotyped for antigens that correspond to commonly encountered and clinically significant alloantibodies ${ }^{[8]}$. Donor cells may have heterozygous (e.g. $\mathrm{K}+\mathrm{k}-)$, homozygous $(\mathrm{K}+\mathrm{k}+)$ expression or no expression of various antigens $(\mathrm{K}-\mathrm{k}-)$. The phenotypes of all the donor cells being tested are shown in a chart. The patient's serum is tested against the various donor cells. Based on the reactions of the patient's serum against the donor cells, a pattern will emerge to confirm the presence of one or more antibodies. Not all antibodies are clinically significant (i.e. cause transfusion reactions, HDN, etc.). Once the patient has developed a clinically significant antibody it is vital that the patient receive antigen-negative red blood cells to prevent future transfusion reactions. A direct antiglobulin test (Coombs test) is also performed as part of the antibody investigation.

If there is no antibody present, an immediate spin crossmatch or computer assisted crossmatch is performed where the recipient serum and donor red blood cells are incubated. In the immediate spin method, two drops of patient serum are tested against a drop of 3-5\% suspension of donor cells in a test tube and spun in a serofuge. Agglutination or hemolysis (i.e., positive Coombs test) in the test tube is a positive reaction and the unit should not be transfused.

If an antibody is suspected, potential donor units must first be screened for the corresponding antigen by phenotyping them ${ }^{[8]}$. Antigen negative units are then tested against the patient plasma using an antiglobulin/indirect crossmatch technique at 37 degrees Celsius to enhance reactivity and make the test easier to read.From the whole blood,packed cells,platelets and fresh frozen plasma are separated.Strict aseptic precautions are followed.

ATRs like allergic reactions(urticaria,itching),(FNHTR)febrile nonhaemolytic transfusion reactions(fever), anaphylactoid reactions(bronchospasm,hypotension)and pulmonary embolism(severe respiratory distress, froth from mouth,collapse)were monitered in recipients of transfusion ${ }^{[9]}$.

\section{Data analysis}

The data collected for this study were analysed for frequency,percentage,mean and standard deviation.Statistical software used was Microsoft excel 2007 and IBM SPSS statistics version 20.The chi square test was used were ever applicable and $\mathrm{p}$ value $<0.05$ was considered significant.

The following parameters were calculated and tabulated.

1) Percentage of component /whole blood transfused.(TABLE-1)

2) Risk of acute transfusion reactions with a particular component/whole blood ${ }^{[10]}$.(TABLE-1)

3) Risk of particular reaction with a particular component/whole blood.(TABLE-2)

4) Percentage of particular reaction in relation to total number transfusion.(TABLE-3)

5) Percentage of particular reaction in relation to total number of acute transfusion reactions.(TABLE-4)

6) Percentage of units received by various clinical departments in the hospital.(TABLE-5)

7) Demographic data.(TABLE-6)

IV. Results

Table -1

\begin{tabular}{|l|l|l|l|}
\hline Type of transfusion & $\begin{array}{l}\text { Total number of units transfused } \\
(\mathrm{n}=2445)\end{array}$ & Percentage of units transfused & $\begin{array}{l}\text { Total number of acute } \\
\text { transfusion } \\
\text { reactions.(n=16) }\end{array}$ \\
\hline Whole blood & 1330 & $54.39 \%$ & 7 \\
\hline Packed cells & 950 & $38.8 \%$ & 2 \\
\hline Platelet rich plasma & 65 & $2.6 \%$ & 4 \\
\hline Fresh frozen plasma & 100 & $4.08 \%$ & 3 \\
\hline
\end{tabular}

Table-2

\begin{tabular}{|l|l|l|l|l|l|}
\hline Type of transfusion reaction & $\begin{array}{l}\text { Whole blood } \\
(\mathrm{n}=1330)\end{array}$ & $\begin{array}{l}\text { Packed } \\
\text { cells } \\
(\mathrm{n}=950)\end{array}$ & $\begin{array}{l}\text { Platelet rich plasma } \\
(\mathrm{n}=65)\end{array}$ & $\begin{array}{l}\text { Fresh frozen } \\
\text { plasma } \\
(\mathrm{n}=100)\end{array}$ & $\begin{array}{l}\text { Total } \\
(\mathrm{n}=2445)\end{array}$ \\
\hline Allergic reaction & 4 & 1 & 2 & 1 & 8 \\
\hline $\begin{array}{l}\text { Febrile nonhaemolytic transfusion } \\
\text { reaction }\end{array}$ & 2 & 1 & 2 & 1 & 6 \\
\hline Anaphylactiod reaction & 1 & Not & Not reported & 1 & 2 \\
\hline
\end{tabular}


Study Of Haemovigilance In A Tertiary Care Teaching Hospital Inandhrapradesh

\begin{tabular}{|l|l|l|l|l|l|}
\hline & & reported & & & \\
\hline Pulmonary embolism & Not reported & $\begin{array}{l}\text { Not } \\
\text { reported }\end{array}$ & Not reported & Not reported & Nil \\
\hline
\end{tabular}

Table-3

\begin{tabular}{|l|l|l|}
\hline Type of transfusion reaction & Number of transfusion reactions & $\begin{array}{l}\text { Percentage of transfusion reactions in } \\
\text { relation to total no of transfusions }(\mathrm{n}=2445)\end{array}$ \\
\hline Allergy & 8 & $0.33 \%$ \\
\hline $\begin{array}{l}\text { Febrile nonhaemolytic transfusion } \\
\text { reaction }\end{array}$ & 6 & $0.25 \%$ \\
\hline Anaphylactoid reaction & 2 & $0.08 \%$ \\
\hline Pulmonary embolism & 0 & Nil \\
\hline
\end{tabular}

Table-4

\begin{tabular}{|l|l|l|}
\hline Type of transfusion reaction & Number of transfusion reactions & $\begin{array}{l}\text { Percentage of transfusion reactions in } \\
\text { relation to total no of transfusion } \\
\text { reactions(n=16) }\end{array}$ \\
\hline Allergy transfusion & 6 & $50 \%$ \\
\hline $\begin{array}{l}\text { Febrile nonhaemolytic } \\
\text { reaction }\end{array}$ & 8 & $37.5 \%$ \\
\hline Anaphylactoid reaction & 2 & $12.5 \%$ \\
\hline Pulmonary embolism & 0 & Nil \\
\hline
\end{tabular}

Table-5

\begin{tabular}{|l|l|l|}
\hline Type of clinical department & Number of units recieved & Percentage of units received \\
\hline Obstetrics and gynaecology & 1424 & $58.27 \%$ \\
\hline Paediatrics & 212 & $8.6 \%$ \\
\hline Surgical & 133 & $5.4 \%$ \\
\hline Medical & 102 & $4.17 \%$ \\
\hline Others & 574 & $23.47 \%$ \\
\hline
\end{tabular}

Table-6

Demographic characteristics of transfusion receipents reporting acute transfusion reactions

\begin{tabular}{|l|c|}
\hline Gender & $10(62.5 \%)$ \\
Males & $6(37.5 \%)$ \\
Females & \\
\hline Age & $6-72$ years \\
Mean age males & $35 \pm 12.4$ years \\
Mean age females & $32 \pm 18.6$ years \\
\hline Blood group & 4 \\
A+ & 4 \\
B+ & 3 \\
AB+ & 5 \\
O+ & \\
\hline
\end{tabular}

A total of 2445 units of whole blood and components were transfused in the study period,out of which a total of $16(0.65 \%)$ acute transfusion reactions(ATR) were encountered.Table -6 depicts the demographic characteristics of recipients reported with transfusion reactions. The age of recipients reporting ATR is 6-72 years, with mean age of males being $35 \pm 12$.4years and mean age of females being $32 \pm 10.6 y e a r s$. There is male preponderance $(62.5 \%)$ in the frequency of transfusion reactions compared to females $(37.5 \%)$. However this difference is not significant( $p>0.05)$. Transfusion with whole blood was most commonly associated with $\operatorname{ATR}(\mathrm{P}=0.13)$ followed by platelet rich plasma $(\mathrm{p}=0.18)$. Allergic reactions were most commonly encountered $\operatorname{ATR}(p=0.16)^{[11]}$. This is followed by febrile nonhaemolytic transfusion reactions $(p=0.25)$. There was no case of pulmonary embolism during the period of study.TABLE-2 ,shows relative frequency of ATRs.TABLE-3 depicts percentage of ATRs compared to total number of transfusions, where as TABLE-4 shows percentage of ATRs in relation to total number of transfusion reactions. The percentage of transfusions done in individual clinical departments was depicted in TABLE-5.

\section{Discussion}

The concept of haemovigilance was first initiated by French.Haemovigilance system is designed to detected ,gather and analyse unexpected or undesirable effects associated with transfusion.It is thus not only an avenue to analyse blood transfusion incidents but also a tool to measure the effects of new processes or corrective action implemented to remedy their causes and prevent their recurrence. Noninfectious adverse transfusion reactions such as acute haemolytic transfusion reactions,FNHTRs, anaphylactoid reactions, transfusion related acute lung injury and allergic reactions are recognized as predominant constituent 
factors of transfusion related morbidity and mortality ${ }^{[12]}$.ATRs are those immune or nonimmune adverse reactions that occur with in 24 hours of transfusion. The estimated frequency of ATR varies from $0.2 \%$ to $10 \%$ and mortality is approximately 1 in 2,50,000.In this study frequency of ATRs was observed to be $0.65 \%$ which is comparable to that carried out in Sikkim were the incidence is $0.92 \%$.In other study conducted in Punjab the incidence of ATRs was 1.09\%.Two larger studies done in New delhi and Chandigarh however showed a relative lower frequency of ATRs $(0.05 \%$ and $0.018 \%$ respectively).A study in switzerland and at Quebec reported ATRs at the rates of $0.042 \%$ and $0.035 \%$ respectively ${ }^{[13]}$.

The frequency of ATRs was more in males than females though it was not statistically significant.A skewed incidence of transfusion reactions towards females was seen in studies done in Saudi Arabia(54.3\%)and Zimbabwe $(61.6 \%)^{[14]}$.

The most common ATRs observed was allergic reaction(50\% of ATRs)which presented most commonly as urticaria and/or itching.There is no significant difference observed between number of allergic reactions and type of transfusions( $p>0.05$ ). Allergic reactions can occur upto $2 \%$ of transfusions as a result of recipient immunoglobulin $\mathrm{E}$ and donor antigen interaction triggering the release of histamine,leucotrienes and platelet activating factor.Clinically allergic reactions have been discerned from the more severe anaphylactoid reactions by the absence of clinical manifestations such as bronchospasm and/or hypotension.Similar to the findings of this study,allergic reactions were most common ATRs in a study done in Delhi(55.1\%)and $\operatorname{Iran}(49.2 \%)^{[15]}$.Over all incidence of allergic reaction in a study in Delhi was $0.02 \%$ where as it was $0.33 \%$ in our study.It was $0.6 \%$ in a study done in Sikkim.

FNHTR, which is defined as a otherwise unexplained rise in temperature of atleast $1^{\circ}$ during or shortly after transfusion,comprise of $37.5 \%$ of the total ATRs $(0.25 \%$ of total transfusion).In a study in Sikkim it was $28 \%$ of total ATRs and $0.26 \%$ of total transfusions ${ }^{[16]}$.Two FNHTR was seen with whole blood and platelet transfusions.The association was nonsignificant $(\mathrm{p}>0.05)$.A study done in Sikkim showed significant association of FNHTR with packed cell transfusion $(\mathrm{p}<0.05)^{[17]}$.In a study done in AIIMS, the frequency of FNHTRs with packed red blood cells was found to be $0.04 \%$ which is low compared to this study.Leukocyte depleted red blood cells have shown to reduce the incidence of FNHTRs ${ }^{[18]}$.The risk of FNHTR with transfusion of nonleukoreduced whole blood and packed cells was estimated to be $0.114 \%$ in a study done in Chandigarh ${ }^{[19]}$.

There was no case of pulmonary embolism during the three months of the study.In a study done in Sikkim the incidence of pulmonary embolism was $0.09 \%$ compared to all total transfusions ${ }^{[20]}$.

\section{Conclusion}

The overall incidence of ATRs in this institution is more compared to higher institutions like AIIMS but less compared to studies done in north eastern states like Sikkim. There was no significant association among the types of transfusion and ATRs $(p>0.05)$. The use of leuckoreduced whole blood and packed cells possibly reduce ATRs in general and FNHTRs in particular.

\section{References}

[1]. Callum JL, Pinkerton PH. Transfusion reactions. In: Callum JL, Pinkerton PH, editors. Bloody Easy: Blood Transfusions, Blood Alternatives and Transfusion Reactions, A Guide to Transfusion Medicine. Toronto (Ontario): Sunnybrook andWomen's College Health Sciences Centre; 2005. p. 34-65.

[2]. Sahu S, Hemlata, Verma A. Adverse events related to blood transfusion. IndianJ Anaesth 2014;58:543-51.

[3]. Quaranta JF, Canivet N. What is the use of hemovigilance? Transfus Clin Biol1998;5:415-21

[4]. Faber JC. Worldwide overview of existing haemovigilance systems. TransfusApher Sci 2004;31:99-110

[5]. Andreu G, Morel P, Forestier F, Debeir J, Rebibo D, Janvier G, et al. Hemovigilancenetwork in France: Organization and analysis of immediate transfusion incidentreports from 1994 to 1998. Transfusion 2002;42:1356-64.

[6]. Faber JC. Haemovigilance around the world. Vox Sang 2002;83 Suppl 1:71-6

[7]. Kumar P, Thapliyal R, Coshic P, Chatterjee K. Retrospective evaluation ofdverse transfusion reactions following blood product transfusion from a tertiary care hospital: A preliminary step towards hemovigilance. Asian J Transfus Sci 2013;7:109-15

[8]. Menitove JE, McElligott MC, Aster RH. Febrile transfusion reaction: What blood component should be given next? Vox Sang 1982;42:318-21

[9]. Paglino JC, Pomper GJ, Fisch GS, Champion MH, Snyder EL. Reduction of febrile but not allergic reactions to RBCs and platelets after conversion to universal prestorage leukoreduction. Transfusion 2004;44:16-24.

[10]. Hendrickson JE, Hillyer CD. Noninfectious serious hazards of transfusion. Anesth Analg 2009;108:759-69

[11]. Kuriyan M, Carson JL. Blood transfusion risks in the intensive care unit. Crit Care Clin 2004;20:237-53, ix.

[12]. Kumar R, Gupta M, Gupta V, Kaur A, Gupta S. Acute transfusion reactions (ATRs) in Intensive Care Unit (ICU): A Retrospective Study. J Clin Diagn Res 2014;8:127-9.

[13]. Robillard P, Nawej KI, Jochem K. The Quebec hemovigilance system: Description and results from the first two years. Transfus Apher Sci 2004;31:111-22 Mafirakureva N, Khoza S, Mvere DA, Chitiyo ME, Postma MJ, Van Hulst M. Incidence and pattern of 12 years of reported transfusion adverse events in Zimbabwe: A retrospective analysis. Blood Transfus 2014;12:362-7

[14]. Payandeh M, Zare ME, Kansestani AN, Pakdel SF, Jahanpour F, Yousefi H, et al. Descriptions of acute transfusion reactions in the teaching hospitals of Kermanshah university of medical sciences, Iran. Int J Hematol Oncol Stem Cell Res 2013;7:11-6.

[15]. Hendrickson JE, Hillyer CD. Noninfectious serious hazards of transfusion. Anesth Analg 2009;108:759-69 
[16]. Bhattacharya P, Marwaha N, Dhawan HK, Roy P, Sharma RR. Transfusion-related adverse events at the tertiary care center in North India: An institutional hemovigilance effort. Asian J Transfus Sci 2011;5:164-70.

[17]. King KE, Shirey RS, Thoman SK, Bensen-Kennedy D, Tanz WS, Ness PM. Universal leukoreduction decreases the incidence of febrile nonhemolytic transfusion reactions to RBCs. Transfusion 2004;44:25-9.

[18]. Heddle NM, Klama LN, Griffith L, Roberts R, Shukla G, Kelton JG. A prospective study to identify the risk factors associated with acute reactions to platelet and red cell transfusions. Transfusion 1993;33:794-7

[19]. Khalid S, Usman M, Khurshid M. Acute transfusion reactions encountered in patients at a tertiary care center. J Pak Med Assoc 2010;60:832-6. 